\title{
Evaluation of the vegetative and generative performance of new apple cultivars in the Nyírség region
}

\author{
Csihon, Á. \\ University of Debrecen, Faculty of Agriculture, Institute of Horticulture \\ 138. Böszörményi str., Debrecen, H-4032, Hungary
}

\begin{abstract}
Summary: In this paper we examine apple varieties, which are planted expansively in the development apple orchards of the WesternEuropean countries, but about its production characteristics we don't have or just few practical experiences in Hungary. These varieties can be described with regular and high yields, aesthetic and alluring appearance in their origin places, what ensure profitable producing for the growers. Under the Hungarian climate which tends to be often extreme (hard cold winters, late spring frosts, summer drought, heat stress) these varieties may behave differently, so before the substantial planting it is expedient to carry out variety evaluations to avoid the later failures. The place of our experiments is located in the Nyírség representing adequately the ecological conditions of the surrounding areas, so the gained results can be adapted easily in the biggest apple production site of Hungary. Regarding the vegetative and the generative parameters of the 14 examined varieties ('Gala Venus Fengal', 'Gala Decarli-Fendeca', 'Galaval', 'Jugala', 'Gala Schnitzer (S) Schniga', 'Red Cap Valtod (S)', 'Early Red One', 'Jeromine', 'Crimson Crisp (Co-op 39)', 'Red Topaz', 'Wilton's Red Jonaprince', 'Red Idared', 'Fuji September Wonder', club cultivar) we found significant differences. The ratio of the thickness of trunk and the main branches showed that the trees have an optimal canopy structure in accordance with the Zahn principles, so they are in harmonious growing balance. The 'Gala' sport trained to slender spindle produced the highest yields, while the 'Fuji' and the 'Red Delicious' sport trained to super spindle can be described with the lowest values. All the cultivars reached the eating quality $(65-70 \mathrm{~mm})$, from which the 'Red Idared', the 'Red Jonaprince' and the 'Red Cap' produced outstanding fruit size (81-85 mm).
\end{abstract}

Keywords: apple cultivars, adaptability, vegetative performance, generative performance

\section{Introduction}

In most of the Hungarian apple orchards the produced apple yield can be used just for industry purposes due to the outdated technology and the obsolete variety assortment. In the case of the orchards producing principally raw material for the industry the economic production can be maintained hardly. Calculations thanks to the powerful increasing of the competition it is necessary to produce $40-50$ t/acre yields and obtain at least $80 \%$ of the first class fruits to achieve the appropriate economic level in the intensive apple orchards. Reaching these kind of yields and quality requirements is just possible by planting intensive orchards, using varieties with high biological accomplishment and maintain the strict, precise technology.

The variety assortment has a huge role in the success of the production and in the good market positions. Tomcsányi (1973) claims that the characteristics of horticultural products are determined basically by the cultivar and the producing method, while Gyúró et al. (1976) reported that one of the most important requirement of the maximum yields is the planting of cultivars with high productivity. In his study Z. Kis (2002) named the variety changing one of the term of the competitive apple production correlating with G. Tóth and Bodor's (2004) opinion, who considers that in the case of the home apple production the modern cultivars are elemental in the interest of preserving the good market positions. According to Gonda (2005) the increasing demands of the consumers requires the involving of the foreign origin new cultivars into the examinations, the expansion of the variety assortment. Besides the ecological adaptability, the examination of the growing parameters are also important, such as the outlook, the nutrient value and the postharvest characteristics. Szabó (2006) claims, that it can't be a solution anymore to follow 10-20 years later the development apple producer countries, because we sell on the same market, in Europe. We will stay at a disadvantage in the future, if we don't introduce the innovative technological elements in the same time like the Western-European countries do and if we don't realize a similar high level production.

Soltész (2007) reported, that a rich cultivar assortment is available for producers, but in the world apple production just some world variety will have determinative role. Holb et al. (2005) and Gonda and Filep (2011) pointed out that also in Hungary the rich apple variety assortment of the years after the changing system is cleared-out, and in the new plantations five cultivars became dominant ('Gala'-, 'Jonagold'-, 'Golden Delicious'-, 'Red Delicious' sports and 'Idared'). The study of Gonda (2013) revealed, that the relative rapid changing of the apple variety assortment will 
be manifested in the changing and the replacement of the new clones inside the sports.

According to the KSH data the 'Jonathan' cultivar which was dominant in Hungary for many decades has been lost the leading position parallel with the decreasing of the numbers of the out-of-date orchards. The proportion of that cultivar was $16 \%$ in 2012, which meant the second place. The cultivar 'Idared' - hybrid of 'Jonathan' - took the leading position, which is preferred specially by the home consumers $(23 \%)$. After these two cultivar follows the 'Jonagold' $(5,7 \%)$, the 'Golden Reinders' (4,6\%) and the 'Starking Delicious' $(3,7 \%)$. Accordingly the modernisation of the variety assortment has been started, but in the future other changes are essential to achieve good market positions.

Based on the above mentioned it can be stated, that in the case of the new foreign origin cultivars and clones breaded with different methods it would be necessary to choose and make experiments with the most promising candidates. In order to avoid failures it is important to have domestic experiences with the cultivars before the establishment of new plantations, because they can behave differently under diverse ecological conditions. A variety which can be described with permanent, high yield and adequate colouring without rusetting in its place of origin can cause disappointment under the Hungarian climate which often tends to be extreme; therefore it is expedient to carry out variety evaluations before the substantial planting.

The aim of our examinations is to evaluate the generative and the vegetative performance of new foreign origin apple cultivars, which are already produced in the WesternEuropean countries, and according to the positive experiences it would be perspective to involve into the home experiments. Regarding that the place of the trials is located in the Nyírség region which presents adequately the surrounding environment, the achieved result can be adapted well in the biggest home apple producing region as well.

\section{Materials and methods}

Our observations were performed in the orchards of the firm F.N. Fruit Kft, near to the village Nyírbátor in 2013.

The main parameters of the experimental area are the following:

- mean temperature of the year: 10-11 ${ }^{\circ} \mathrm{C}$,

- sunshine hours: 1900-2050 hours/year,

- average precipitation in the last 10 years: $404 \mathrm{~mm}$,

- $\mathrm{pH}: 6,92$,

- humus content: low (1\%), the type of the soil is light sandy,

- the „Arany” number of heaviness: 27-29.
The examined apple cultivars can be grouped by the sports and the resistant characteristics into three groups, and the other varieties are classified into the fourth group (Table 1).

Table 1: The classification of the examined cultivars

\begin{tabular}{|c|c|c|c|}
\hline 'Gala' sport & $\begin{array}{c}\text { 'Red Delicious' } \\
\text { sport } \\
\end{array}$ & $\begin{array}{l}\text { Resistant } \\
\text { cultivars }\end{array}$ & Other cultivars \\
\hline $\begin{array}{l}\text { 'Gala Venus } \\
\text { Fengal' }\end{array}$ & $\begin{array}{l}\text { 'Red Cap Valtod } \\
(\mathrm{S}) \text { ' }\end{array}$ & $\begin{array}{l}\text { 'Crimson Crisp' } \\
\text { (Co-op 39) }\end{array}$ & $\begin{array}{l}\text { 'Wilton's Red } \\
\text { Jonaprince' }\end{array}$ \\
\hline $\begin{array}{l}\text { 'Gala Decarli- } \\
\text { Fendeca' }\end{array}$ & 'Early Red One' & 'Red Topaz' & 'Red Idared' \\
\hline 'Galaval' & 'Jeromine' & & \begin{tabular}{|l} 
'Fuji September \\
Wonder'
\end{tabular} \\
\hline 'Jugala' & & & club cultivar \\
\hline $\begin{array}{l}\text { 'Gala Schnitzer } \\
\text { (S) Schniga' }\end{array}$ & & & \\
\hline
\end{tabular}

The most part of the cultivars were planted in 2011 spring, the smaller part were planted in 2010 autumn, thus all the cultivars developed three vegetation period. The planting material of the cultivars was Knipp tree and one year old tree with branches. The rootstock of the scions is M9, securing the optimal dwarf growing. A distance between the rows is 3,85 $\mathrm{m}$. Regarding the plant-to-plant distance and the canopy two options were formed. In the case of $1 \mathrm{~m}$ plant-to-plant distance slender spindle was created, and in the case of 0,5 m super spindle. The detailed planting design is shown in the Table 2.

The plant protection is carried in accordance with the integrated management principles. The trees of the orchard

Table 2: The planting design of the examined apple cultivars

\begin{tabular}{|c|c|c|c|c|c|}
\hline & $\begin{array}{c}\text { Year of } \\
\text { planting }\end{array}$ & Scion & Rootstock & Spacing & Canopy \\
\hline 'Fengal' & 2011 spring & knipp tree & M9 & $3.85 \mathrm{~m} \mathrm{x} 1 \mathrm{~m}$ & slender spindle \\
\hline 'Fendeca' & 2011 spring & knipp tree & M9 & $3.85 \mathrm{~m} \mathrm{x} 1 \mathrm{~m}$ & slender spindle \\
\hline 'Galaval' & 2011 spring & knipp tree & M9 & $3.85 \mathrm{~m} \times 1 \mathrm{~m}$ & slender spindle \\
\hline 'Jugala' & 2011 spring & knipp tree & M9 & $3.85 \mathrm{~m} \mathrm{x} 1 \mathrm{~m}$ & slender spindle \\
\hline 'Schniga' & 2010 autumn & $\begin{array}{l}\text { one year old } \\
\text { tree with } \\
\text { branches }\end{array}$ & M9 & $3.85 \mathrm{~m} \times 1 \mathrm{~m}$ & slender spindle \\
\hline 'Red Cap' & 2011 spring & knipp tree & M9 & $3.85 \mathrm{~m} \times 0.5 \mathrm{~m}$ & super spindle \\
\hline $\begin{array}{l}\text { 'Early Red } \\
\text { One' }\end{array}$ & 2011 spring & knipp tree & M9 & $3.85 \mathrm{~m} \mathrm{x} 0.5 \mathrm{~m}$ & super spindle \\
\hline 'Jeromine' & 2010 autumn & knipp tree & M9 & $3.85 \mathrm{~m} \mathrm{x} 1 \mathrm{~m}$ & slender spindle \\
\hline $\begin{array}{l}\text { 'Crimson } \\
\text { Crisp' }\end{array}$ & 2011 spring & knipp tree & M9 & $3.85 \mathrm{~m} \mathrm{x} 1 \mathrm{~m}$ & slender spindle \\
\hline 'Red Topaz' & 2011 spring & knipp tree & M9 & $3.85 \mathrm{~m} \times 0.5 \mathrm{~m}$ & super spindle \\
\hline $\begin{array}{l}\text { 'Red } \\
\text { Jonaprince' }\end{array}$ & 2011 spring & $\begin{array}{l}\text { one year old } \\
\text { tree with } \\
\text { branches }\end{array}$ & M9 & $3.85 \mathrm{~m} \times 0.5 \mathrm{~m}$ & super spindle \\
\hline 'Red Idared' & 2010 autumn & $\begin{array}{l}\text { one year old } \\
\text { tree with } \\
\text { branches }\end{array}$ & M9 & $3.85 \mathrm{~m} \mathrm{x} 1 \mathrm{~m}$ & slender spindle \\
\hline 'Fuji SW' & 2011 spring & knipp tree & M9 & $3.85 \mathrm{~m} \mathrm{x} 1 \mathrm{~m}$ & slender spindle \\
\hline club cultivar & 2010 autumn & $\begin{array}{l}\text { one year old } \\
\text { tree with } \\
\text { branches }\end{array}$ & M9 & $3.85 \mathrm{~m} \mathrm{x} 1 \mathrm{~m}$ & slender spindle \\
\hline
\end{tabular}


are fixed to the trellis system, the water supply is solved with dropping irrigation system.

It is important to emphasize that in the year of the examinations (2013) heavy frost damage occurred in spring (17th of march: $-17,3{ }^{\circ} \mathrm{C}$ ), therefore fruit thinning intervention was not performed. With the total and specific yields of the cultivars their each productivity is well presentable in the years with frost damage.

Concerning the club cultivar, we would like to highlight, that its propagation, producing and trading is allowed just for the members of club. In the orchard near to Nyírbátor just 20 trees were planted with the aim of cultivar evaluation.

To describe the vegetative and the generative characteristics of the varieties we signed 7 pieces of tree per each cultivar. From the examined parameters we present the followings in this study:

Parameters regarding the vegetative performance:

$>$ trunk cross sectional area $\left(\mathrm{cm}^{2}\right)$,

$>$ height of the tree $(\mathrm{cm})$,

$>$ ratio of the thickness of the main brunches and the trunk (ZAHN, 1975),

$>$ the number and the thickness of the branches of the central axis in different height level (pieces, $\mathrm{mm}$ ).

Parameters regarding the generative performance:

- fruit size (mm), shape index,

- yields (kg/tree, pieces/tree),

- specific parameter:

$>$ yield/trunk cross sectional area (pieces $/ \mathrm{cm}^{2}, \mathrm{~kg} / \mathrm{cm}^{2}$ ).

\section{Results}

Figure 1 shows the complex index of the vegetative accomplishment, the trunk cross sectional area and the height of trees. Substantial differences are found among the varieties. The members of Gala sport

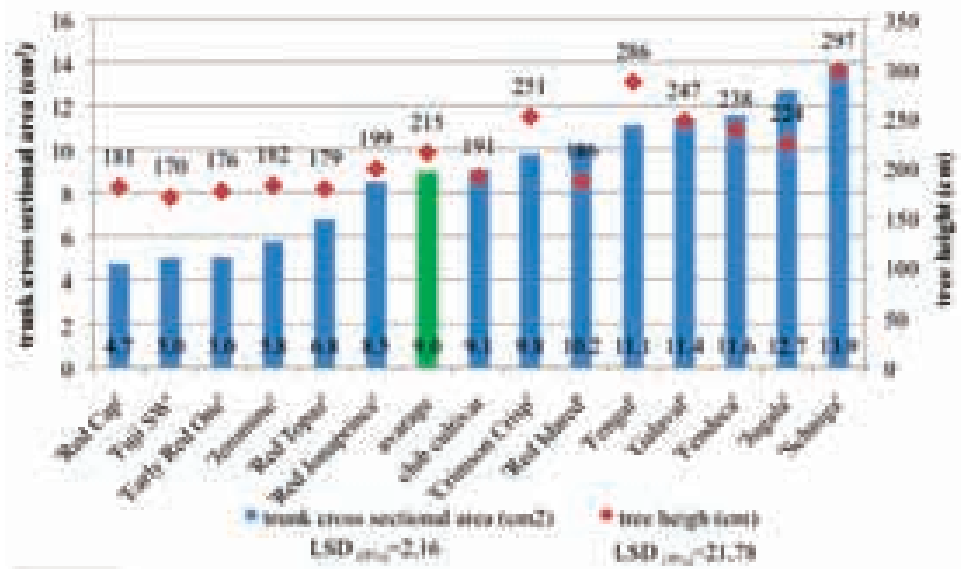

Figure 1: Trunk cross sectional area (TCSA) and tree height of apple cultivars $\left(\mathrm{cm}^{2}, \mathrm{~cm}\right)$ (Nyírbátor, 2013)

In Figure 2, regarding the ratio of the thickness of the brunches and the trunk (Zahn-index) the cultivars present 0,3-0,5 value. Thus extreme thickening or tapering of the main branches are not occurred none of the varieties, so growing harmony can be seen between the trunk and the brunches facilitating the higher productivity. Only the cultivar 'Jeromine' $(0,53)$ exceeded slightly the limiting value $(0,5)$.

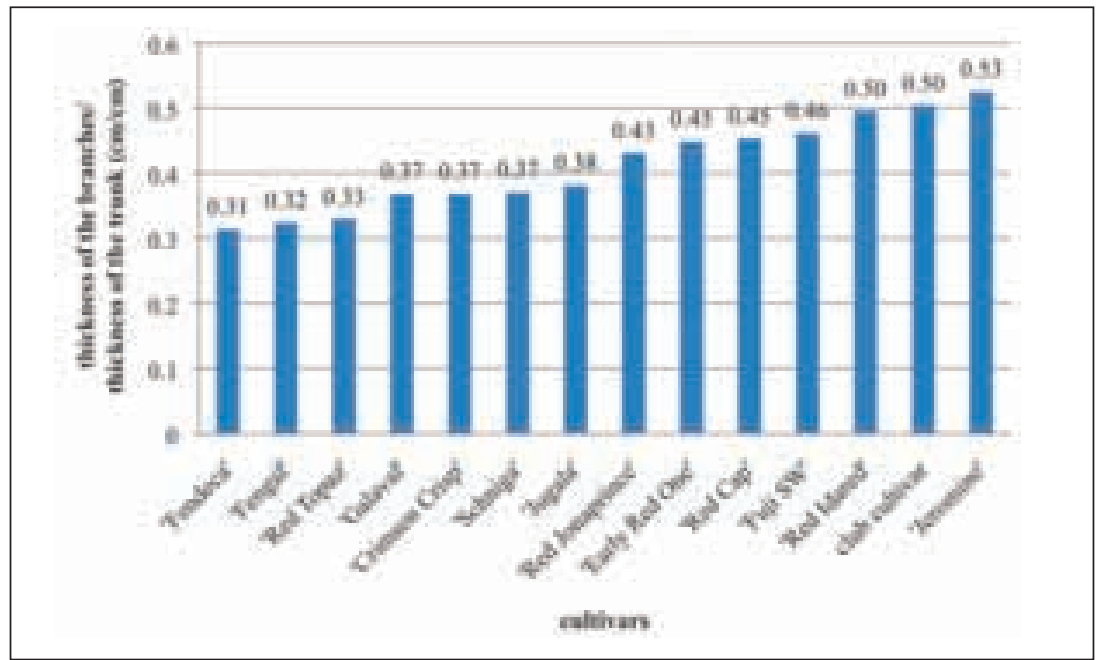

Figure 2: The Zahn-index of the main branches of apple cultivars (Nyírbátor, 2013) ('Schniga', 'Jugala', 'Fendeca', 'Galaval', 'Fengal') reached the biggest trunk thickness (11,1-13,9 $\left.\mathrm{cm}^{2}\right)$. The 'Red Idared', the 'Crimson Crisp' and the club cultivar have got higher thickness then the average. The 'Red Cap', the 'Early Red One' and the 'Red Topaz' display lower values, but they were planted with $0,5 \mathrm{~m}$ planting distance, therefore the smaller trunk size can be judged consistent. It is interesting, that the 'Red Jonaprince', trained to also super spindle showed nearer value to the average. However despite the bigger spacing the 'Fuji' can be described with lower size.

Concerning the tree height similar tendencies can be seen, but beyond the 'Gala' cultivars (2,2-3 m) the 'Crimson Crisp' also reached higher values (2,5 m).
In the case of the thickness of the branches of the central leader (Figure 3) the most cultivars showed the traditional spindle form referring the phenomena that the thickness of the branches tapers from the ground to the top. Just two varieties showed different tendency; the canopy of the 'Fengal' displays stronger brunches in the middle and in the upper region (150-250 cm), and the brunches of 'Fuji SW' tends to be too strong in the higher region $(150-200 \mathrm{~cm})$.

The number of the branches of the central leader ensures us good information about the ability of the ramification of the cultivars (Figure 4). In this case different results are observed. In the majority of the varieties the number of the brunches are decreasing going from the ground to the top ('Fendeca', 


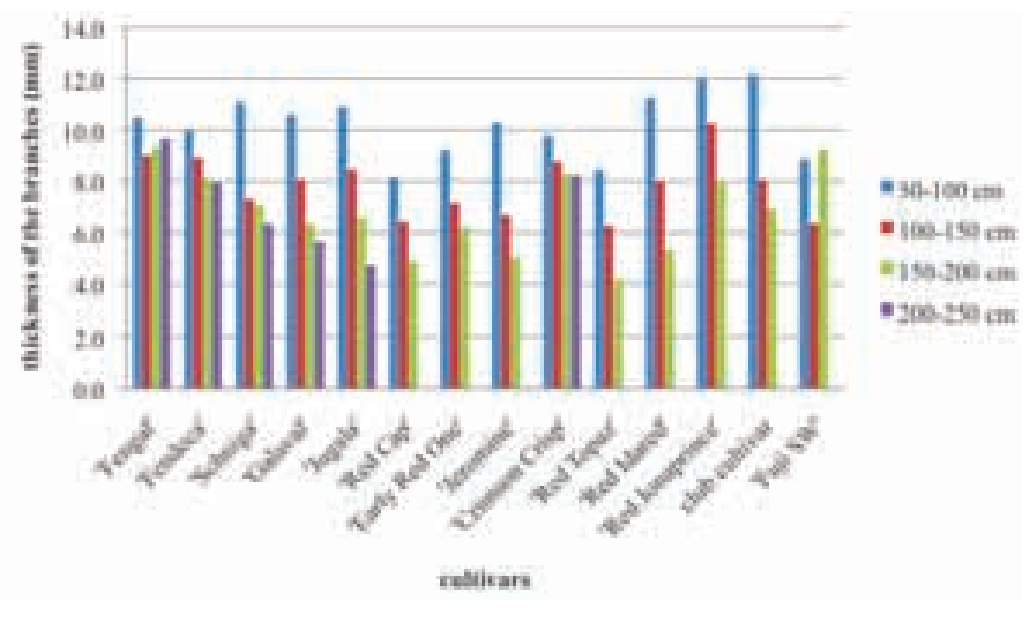

Figure 3: Average thickness of the branches of the central leader in different height zones (mm) (Nyírbátor, 2013)

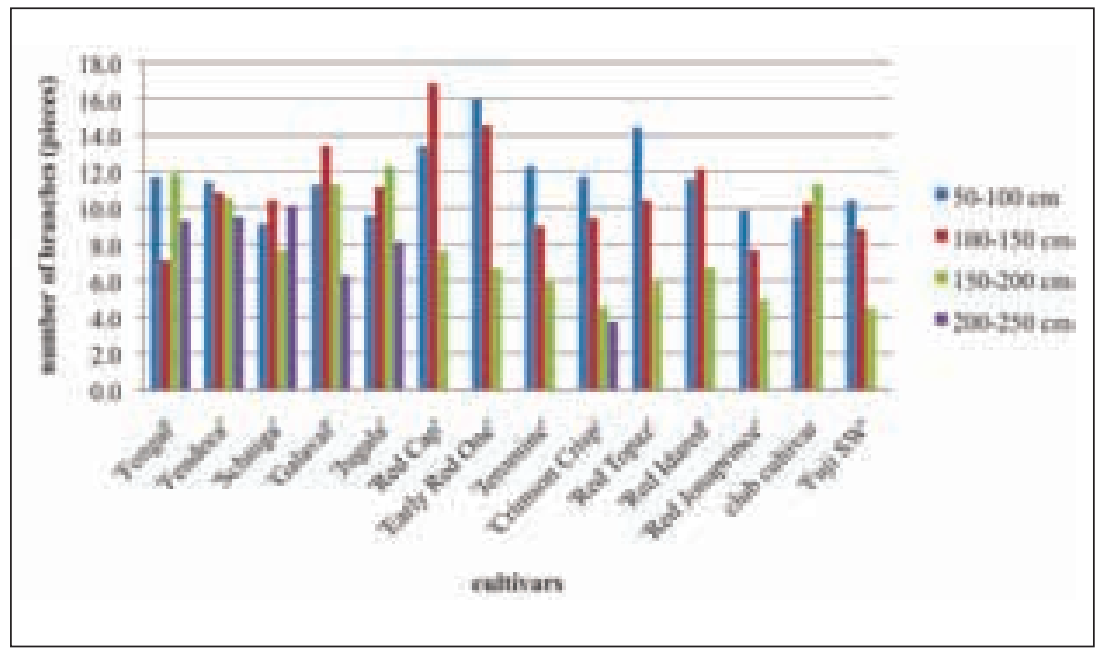

Figure 4: Average number of the branches in different height zones of the central leader (pieces) (Nyírbátor, 2013)

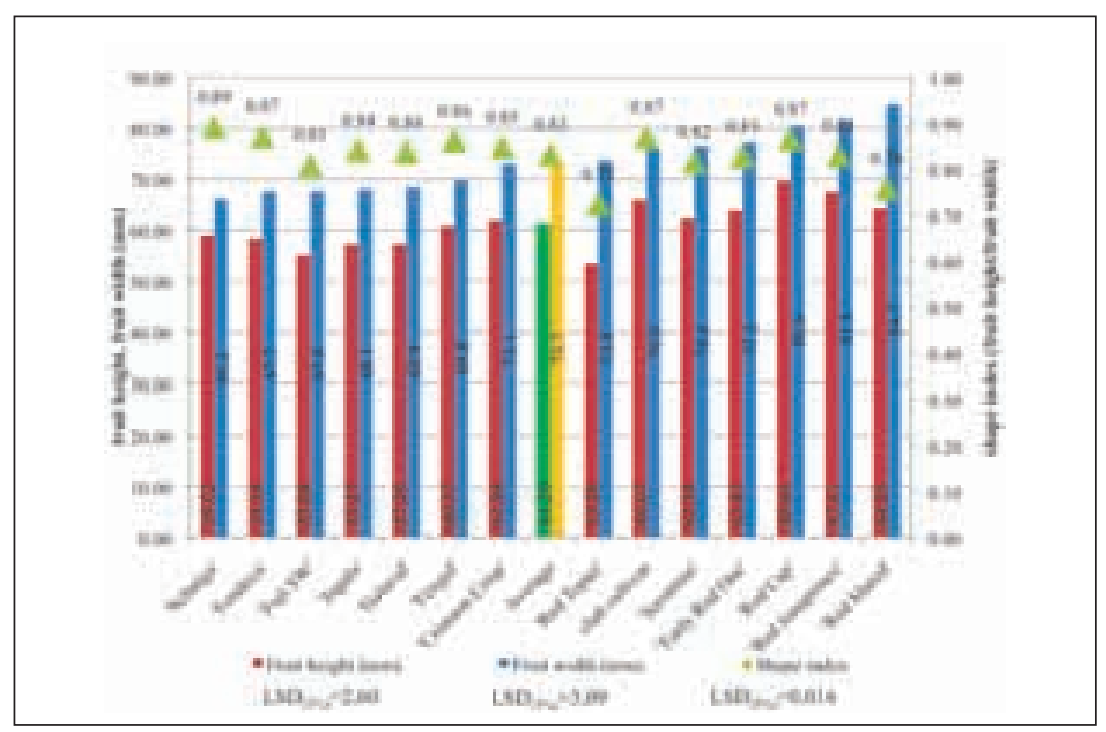

Figure 5: Fruit size and shape-index of the apple cultivars (Nyírbátor, 2013)
'Early Red One', 'Jeromine', 'Crimson Crisp', 'Red Topaz', 'Red Jonaprince' Fuji SW'). The club cultivar can be described with an opposite tendency. The other cultivars showed a slight disproportion of the canopy with the higher number ('Galaval', 'Jugala', 'Red Cap', 'Red Idared') or with lower number of the brunches ('Fengal', 'Schinga') in the certain regions. Negative peculiarity can be discovered in the case of the cultivar 'Crimson Crisp', practically the higher region of the canopy has no ability to ramify.

The data of the fruit size presents significant differences among the cultivars (Figure 5). The least values were performed in the case of the 'Gala' sport (66-69 mm), but as we can seen in the Figure 6, these cultivars produced the highest yields. Furthermore as we know their fruits are genetically smaller than the other varieties, therefore the result can be natural. However, even so, we could pick fruits larger than $65 \mathrm{~mm}$, what makes possible the fresh market trading. This fact shows well the productivity of the sport.

The largest fruits were harvested from the 'Red Idared' $(85 \mathrm{~mm}$ ) which means similar or larger size than the origin cultivar. The 'Red Jonaprince' and the ,Red Delicious' sport (,Red Cap', ,Early Red One', ,Jeromine') produced also huge fruits $(77-82 \mathrm{~mm})$.

Regarding the shape-index preserving the characteristics of the origin cultivars two varieties mark out, the flat 'Red Idared' and the 'Red Topaz' $(0,72-0,76)$. The other cultivars have the usual 0,85 value, including also the 'Red Delicious' sport, which didn't showed its regular elongated shape.

Regarding the yield (Figure 6), similarly to the trunk thickness, the 'Gala' cultivars showed the highest values statistically verifiable, from which we should distinguish the 'Fengal', the 'Fendeca' and the 'Schniga' which achieved the highest number of fruit (128-135 pieces) and the highest yield per tree $(13-18 \mathrm{~kg})$. In the case of the latter cultivar the trees can be considered overloaded, because compared with the 'Fengal' and 'Fendeca' we observed lower fruit weight, but the number of the fruits was similar.

Most of the other variety produced $5-8,5 \mathrm{~kg}$ fruit per tree. This can be a judged positively in the case of the cultivars what were trained to super spindle, because the smaller canopy didn't caused significantly lower yields. Among the examined cultivars 


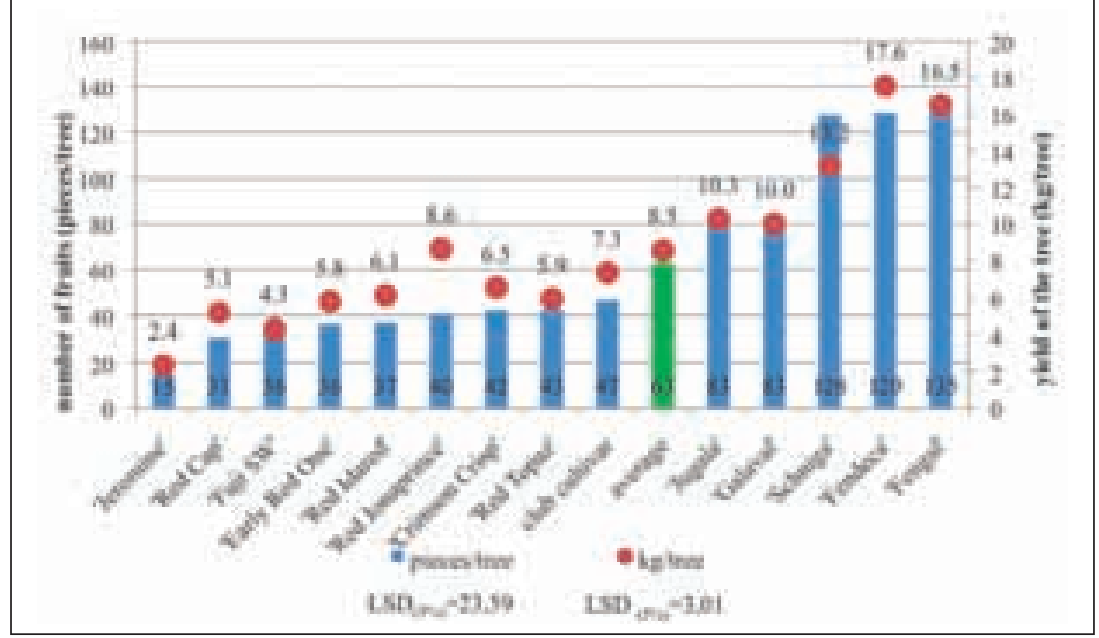

Figure 6: Yields per tree of apple cultivars (pieces/tree, kg/tree) (Nyírbátor, 2013)

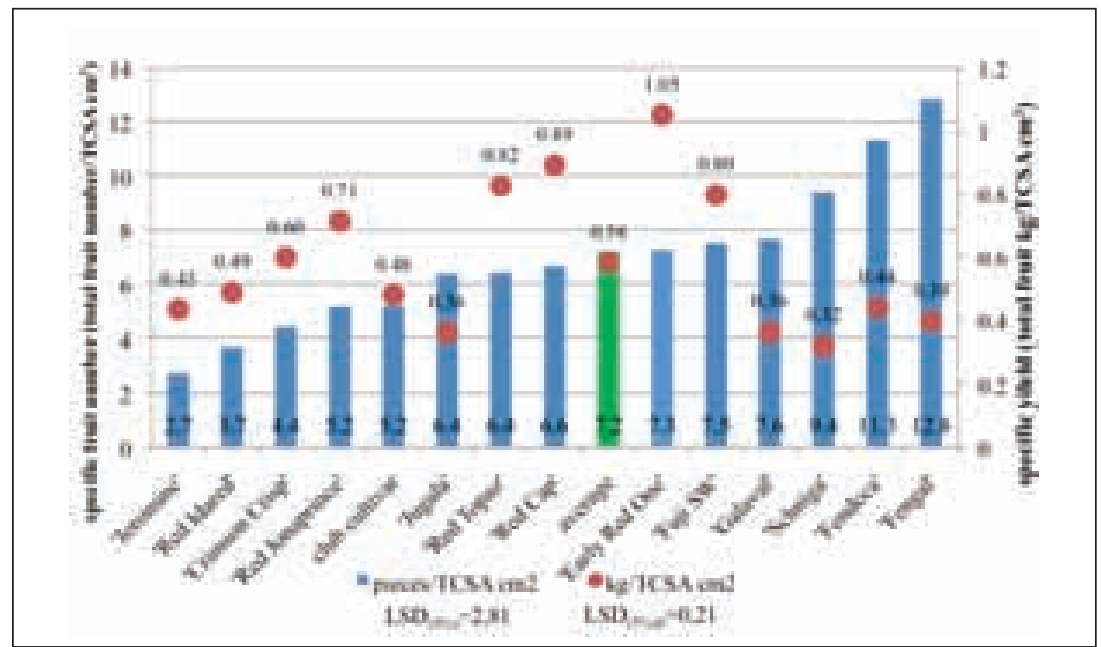

Figure 7: Specific yield of apple cultivars (pieces/TCSA cm², $\left.\mathrm{kg} / \mathrm{TCSA} \mathrm{cm}{ }^{2}\right)($ Nyírbátor, 2013)

the 'Jeromine' presented the less generative accomplishment $(2,4 \mathrm{~kg} / \mathrm{tree})$.

Figure 7 shows the specific yields of the cultivars. The highest values were observed with the 'Early Red One', 'Red Cap' and 'Red Topaz', trained to super spindle and the Fuji $\mathrm{SW}$, trained to slender spindle $\left(0,8-1,05 \mathrm{~kg} / \mathrm{cm}^{2}\right)$.

The 'Gala' cultivars which produced the most total fruit on the tree (10-18 kg/tree) showed also the most advantageous results with the specific fruit number $\left(7,5-13\right.$ pieces $\left./ \mathrm{cm}^{2}\right)$, but performed the lowest specific yield $\left(0,32-0,44 \mathrm{~kg} / \mathrm{cm}^{2}\right)$. This is due to the smaller fruit sizes.

\section{Conclusions}

According to our results in the vegetative and generative accomplishment of cultivars significant differences are found in the experimental area. These differences are the result of the genetically coded characteristics of the varieties, the effects of the vintage, the different training methods and the correlations of these factors.
Regarding the trunk thickness and the tree height of the cultivars which are in the same age ( 3 vegetation period), the 'Gala' sport produced the highest value (trained to slender spindle), while the 'Fuji SW' and the 'Red Delicious' sport (the latter one trained to super spindle) can be described with the least value. The ratio of the thickness of trunk and the main branches showed that the trees have an optimal canopy structure in accordance with the Zahn principles, so they are in harmonious growing balance.

The number and the thickness of the brunches of the central axis which are important peculiarities regarding the maintaining of the canopy, also showed clear differences among the cultivars. Almost all the varieties have got adequate brunch thickness on the central axis going from to ground to the top, which means a decreasing tendency correlating with the optimal spindle canopy structure. According to our examinations it can be stated in the case of cultivars with slender spindle and super spindle canopy as well. In the majority of the varieties concerning the number of the brunches the division of the ramification inside the canopy can be considered proportional, but for example the 'Jugala', 'Crimson Crisp' and the club cultivar can display disproportion in certain part of the canopy, which could result in too dense or too rare canopy.

Due to the heavy cold temperatures in March fruit thinning was not carried out, therefore the size of the fruits are related with the natural fruit load of tree. All the cultivars reached the eating quality $(65-70 \mathrm{~mm})$, from which the 'Red Idared', the 'Red Jonaprince' and the 'Red Cap' produced outstanding fruit size $(81-85 \mathrm{~mm})$.

The data of the yields are strongly related with the size of trees (TCSA, tree height), accordingly the 'Gala' sport trained to slender spindle produced the highest yields, while the 'Fuji' and the 'Red Delicious' sport trained to super spindle can be described with the lowest values. But regarding the data of the specific yields the 'Fuji' and two cultivar of the 'Red Delicious' sport ('Early Red One', 'Red Cap') achieved the best result, thus correlating to the trunk cross sectional area the yield of these varieties are not lower. The cultivar 'Jeromine' showed low productivity in absolute and in specific yields too in the year of the examinations.

\section{References}

G. Tóth M. \& Bodor P.: (2004): Almafajták értékelése a hazai termeszthetőség és a vásárlói megítélés szempontjából. Kertgazdaság. 36 (3): 3-14. 
Gonda I. (2005): Mi lesz veled magyar alma? (2) Tények és esélyek. Kertészet és kertépítészet I. (5): 15-16.

Gonda I. \& Fülep I. (2011): Az almatermesztés technológiája. Debreceni Egyetem Agrár- és Gazdaságtudományok Centruma, Kutatási és Fejlesztési Intézet. Gonda István Betéti Társaság. F.N. Fruit Kft. 260. pp.

Gonda I. (2013): Az alma termesztése - Müvelési rendszerek. [In: Magyarország kultúrflórája - Az alma.] Szerk. TÓTH M. Agroinform Kiadó. 223-228. pp.

Gyuró F., Soltész, M. \& Nyéki J. (1976): Fajtatársítás az alma- és körte ültetvényekben. Kertgazdaság. 8 (1): 1-13.

Holb I., Veisz J., Medgyessy I. \& Abonyi F. (2005) Az alma komplex ökológiai növényvédelmi technológiája. [In: Holb I (szerk.) A gyümölcsösök és a szőlő ökológiai növényvédelme.] Mezőgazda Kiadó, Budapest, pp. 138-144
KSH (2008): Alma-, körte-, õszibarack-, kajszibarack-ültetvények adatai, 2007.

KSH (2013): Alma-, körte-, kajszi- és őszibarackültetvények adatai, 2012

Soltész, M. (2007): Termesztési, piaci és fogyasztási tendenciák az almánál. [Ágazatspecifikus innováción alapuló projektek generálása az alma ágazatban.] Szerk.: Felföldi János. Debrecen. Szaktanácsadási füzetek 15: 27-43

Szabó Z. (2006): Klubfajták. Kertészet és Szőlészet. 55 (12): 10-11.

Tomcsányi P. (1973): Piacos kertészet. Mezőgazdasági Kiadó. Budapest. 632. pp.

Z. Kis L. (2002): Versenyképességünk egyik feltétele a fajtaváltás. Kertészet és Szőlészet. 51 (3): 15. pp.

Zahn F. G. (1975): Mabstabe für die Anzucht und den Schitt der Obstgehölze. Mitteilungen des OVR Jork 30: 93-109. 